\title{
EFFECTIVENESS TEST OF NIPAH EXTRACT AS LARVACIDE ON MOSQUITO LARVAE (Aedes aegpti)
}

\author{
Thadeus Mariode Triputra Purba ${ }^{1 *}$, Irwan Effendi ${ }^{2}$, Feliatra $^{2}$ \\ ${ }^{1}$ Student of The Faculty of Fisheries And Marine Science University of Riau, Pekanbaru \\ ${ }^{2}$ Lecturer at the Faculty Of Fisheries And Marine Science University Riau, Pekanbaru \\ *deonatathadeus2@gmail.com
}

\begin{abstract}
This research was conducted in January - February 2019. The purpose of this study was to examine the effectiveness of mangrove extracts on stems and fruit on the growth of Aedes aegypti mosquito larvae and to know Lethal Concentration $\mathrm{LC}_{50}$ and Lethal Time $\mathrm{LT}_{50}$. The method used is the experimental method, with the experimental design is a completely randomized design (CRD). The treatment of nipah fruit and stem extract concentrations was $3 \%, 6 \%$ and $9 \%$ with contact time of 15 minutes, 30 minutes, 45 minutes 60 minutes, 120 minutes, 480 minutes and the number of replications 3 times with 2 trials. To find out $\left(\mathrm{LC}_{50}\right)$ and $\left(\mathrm{LT}_{50}\right)$, the data was analyzed using the SPSS program. The sample of this research is stem and nipah fruit taken in the mangrove area of Kayu Ara Village, Siak Regency. Aedes aegypti larvae are taken at a water reservoir next to the Arfaunas Mosque in Tampan District. The results showed that the stem and nipah fruit extracts had effective killing power against Aedes aegpti larvae. The extract that was more effective in killing mosquito larvae was the nipah fruit extract compared to the nipah stem extract seen in the number of larval deaths with $\mathrm{LC}_{50}=3.398 \%$ and $\mathrm{LT}_{50}=3.540$ hours. This shows that the level of toxicity is quite toxic.
\end{abstract}

Keywords: Extract, Nipah Steam, Nipah Fruit, Larva Aedes aegypti, $L C_{50}, L C_{50}$.

\section{Pendahuluan}

Hutan mangrove memiliki karakteristik biasanya tumbuh di daerah intertidal yang dimana jenis tanahnya itu berlumpur, berlempung dan berpasir, tergenang air yang secara berkala setiap hari maupun ketika pasang purnama. Mangrove mempunyai banyak sekali manfaat yang bersinggungan langsung dengan kehidupan manusia di daratan, mulai dari manfaat ekologi sampai dengan sebagai sumber pangan dan obat. (Saputra, 2016).

Nipah adalah sejenis palem yang banyak tumbuh di berbagai wilayah Indonesia. Tanaman tersebut banyak tumbuh di dataran rendah berair seperti di rawa-rawa, sekitar sungai, waduk dan sepanjang garis pantai pasang surut.

Sebagian besar tanaman nipah tumbuh secara alami atau belum ada masyarakat yang membudidayakannya secara intensif, hal tersebut disebabkan karena manfaat nipah bagi masyarakat masih terbatas pada penggunaan daun sebagai atap rumah dan anyaman dalam jumlah yang relatif kecil. Buah nipah merupakan hasil hutan yang sifatnya musiman dengan buah yang melimpah setiap musimnya. Sebagian besar nipah yang ada di Indonesia hanya digunakan sebagai tanaman konservasi, belum ke arah tanaman industri. Nipah juga memiliki manfaat sebagai obat tradisional dan kandungan dari tumbuhan ini salah satunya dapat digunakan sebagai antioksidan. Disamping sebagai obat tradisional, nipah (Nypa fruticans) 
mengandung ekstrak aktif yang bermanfaat untuk menghambat penyakit yang disebabkan oleh radikal bebas di dalam tubuh (Afrizal dan Pato, 2017).

Penyakit-penyakit yang umumya ditularkan melalui vektor merupakan penyakit endemis pada daerah tertentu antara lain, Demam Berdarah Dengue (DBD). Demam Berdarah Dengue (DBD) adalah penyakit demam akut yang disebabkan oleh virus dengue yang masuk ke peredaran darah manusia melalui gigitan nyamuk dari genus Aedes. Aedes aegypti dan Aedes albopictus merupakan vektor utama penularan penyakit DBD (Kementerian Kesehatan RI, 2015).

Secara nasional, jumlah penderita Demam Berdarah Dengue (DBD) yang telah dilaporkan selama kurun waktu 20102014 bersifat fluktuatif. Selain itu, adapun rata-rata jumlah kasus bulanan dari tahun 2010-2014, bulan Januari merupakan bulan dengan laporan kasus DBD tertinggi dari pada bulan lainnya, hal ini diakibatkan karena telah terjadi musim penghujan di bulan tahun sebelumnya sehingga tempat perkembangbiakan nyamuk bertambah banyak dan mengakibatkan populasi nyamuk meningkat (Kementerian Kesehatan RI, 2015).

Pemberantasan A. aegypti saat ini merupakan cara utama yang dilakukan untuk memberantas DBD, karena vaksin untuk mencegah dan obat untuk membasmi virusnya belum tersedia. Pemberantasan dapat dilakukan secara kimia, biologi, dan fisik terhadap nyamuk $A$. aegypti dewasa atau jentiknya. Adapun tujuan penelitian ini adalah Mengetahui efektivitas ekstrak mangrove pada batang dan buah terhadap pertumbuhan larva nyamuk $A$. aegypti. Mengetahui pada konsentrasi berapa ekstrak nipah Lethal Concentration $\mathrm{LC}_{50}$ (batang dan buah) efektif sebagai larvasida terhadap pertumbuhan larva A. Aegypti. Mengetahui waktu yang dibutuhkan ekstrak nipah Lethal Time $\mathrm{LT}_{50}$ (batang dan buah) untuk membunuh larva nyamuk $A$. aegypti.

\section{Metode Penelitian}

Penelitian ini dilaksanakan pada bulan Februari - Maret 2019 di Laboratorium Mikrobiologi Laut, Laboratorium Bioteknologi Laut Jurusan Ilmu Kelautan dan Laboratorium Kimia Ilmu Kelautan, Fakultas Perikanan dan Kelautan, Universitas Riau. Alat dan bahan yang digunakan selama peneltian yaitu Ekstrak Batang dan Buah Nypa fruticans, Air Payau, Alkohol 70\%, Aquades, Larva Aedes aegpti, Parang, Hand Refractometer, $\mathrm{pH}$ indikator, cangkul, kamera, dan plastik.

\section{Metode Penelitian}

Metode yang digunakan dalam penelitian ini adalah metode eksperimen, menggunakan Rancangan Acak Kelompok (RAL) dengan 20 larva pada masingmasing perlakuan. Terdapat ekstrak uji batang dan buah Nypa fruticans dengan tiga pemberian konsentrasi yang berbeda dengan tiga kali pengulangan yaitu $3 \%$ (P1), $6 \%(\mathrm{P} 2), 9 \%(\mathrm{P} 3)$, dan dengan dua kontrol yaitu, kontrol positif $(\mathrm{K}+)$ yang berisi ABATE 1 gr dan kontrol negatif (K-) yang berisi aquades. Kombinasi Perlakuan yaitu : pada sampel ekstrak batang mangrove nipah tersebut baik itu batang dan buah pada sampel 3, 6, dan 9\% terdapat semua larva nyamuk mati semua dalam waktu yaitu beberapa menit, terjadinya penghambatan pada larva nyamuk tersebut.

\section{Pengambilan Sampel}

Pengambilan sampel Nypa fruticans dilakukan di ekosistem hutan mangrove Stasiun Desa Sungai Kayu Ara, Siak, Provinsi Riau. Sampel Nypa fruticans diambil pada bagian batang dan buah Nypa fruticans yang telah dikumpulkan dan dimasukkan kedalam plastik selanjutnya 
dibawa ke Laboratorium Bioteknologi Laut di Universitas Riau, Pekanbaru.

\section{Pengukuran Kualitas Perairan}

Pengukuran kualitas perairan dilakukan dengan mengukur aspek fisika dan kimia.Parameter fisika meliputi suhu dan salinitas, sedangkan parameter kimia yang diukur adalah $\mathrm{pH}$. Pengukuran kualitas perairan dilakukan saat penelitian.

\section{Pembuatan Ekstrak Nipah (Nypa fruticans)}

Pembuatan Ekstrak Nypa fruticans dilakukan di Laboratorium Bioteknologi Laut, dan Laboratorium Kimia jurusan ilmu kelautan, Fakultas Perikanan dan Kelautan, Universitas Riau, sampel Nypa fruticans (batang dan buah) dicuci, lalu dikeringkan dan ditimbang ditimbang sebanyak 10 gram lalu dipotong halushalus selanjutnya dihancurkan dengan menggunakan mortal penghalus dan diblender sampel batang dan buah nipah tersebut. (Sefrinus et al., 2018).

Sampel yang telah halus kemudian diaduk dan diberi sedikit tambahan alkohol $70 \%$ secukupnya kurang lebih $50 \mathrm{ml}$ selama kurang lebih 2 jam agar seluruh sampel terendam secara merata. Selanjutnya baru dilakukan pemerasan untuk pengambilan ekstrak pada batang dan buah magrove nipah tersebut, pengambilan ekstrak nipah tersebut dilakukan dengan menggunakan saringan saat pemerasan ekstrak yang akan diambil. Untuk ekstrak yang dibutuhkan nanti 3\%, $6 \%$ dan $9 \%$.

\section{Penyediaan Jentik Nyamuk}

Penyediaan jentik nyamuk ini diawali dengan mencari biakan jentik nyamuk yang ada dipenampungan air di samping Masjid Arfaunas. Biakan jentik nyamuk didapatkan dari tempat yang tersedia di daerah kota pekanbaru. Biakan jentik nyamuk yang didapatkan lalu dibawa ke Laboratorium Bioteknologi Jurusan
Ilmu Kelautan, Fakultas Perikanan dan Kelautan, Universitas Riau.

\section{Identifikasi Larva Nyamuk}

Identifikasi larva nyamuk dilakukan dengan cara mengambil larva dari tempat yang selokan atau parit di pinggir jalan dengan menggunakan gayung/cidukan kemudian dimasukan ke dalam wadah dan diberi label untuk selanjutnya dibawa ke laboratorium untuk diidentifikasi. Sebelum proses identifikasi, larva dikeluarkan dari botol dengan menggunakan pipet tetes kemudian direndam dalam alkohol $70 \%$. Larva nyamuk diletakkan di atas obyek glass dan ditutup dengan deck glass kemudian diamati di bawah mikroskop perbesaran lensa obyektif 10 x 40. Larva nyamuk diidentifikasi spesiesnya dengan menggunakan buku atlas parasitologi. (Fitri et al.,2016).

\section{Persiapan Media Air Payau}

Adapun tahapan dalam pembuatan air payau tersebut sebagai berikut :

1. Air tawar yang sudah disediakan diletakkan pada suatu wadah \pm 10 L.

2. Media air laut yang terlebih dahulu sudah diukur salinitasnya dan dicampurkan untuk air laut yang bersalinitas 30\%.

3. Air tawar dan air laut diaduk agar tercampur sempurna dan di diamkan \pm 30 menit

4. Media air siap digunakan untuk percobaan penelitian.

Untuk menghitung perbandingan jumlah air tawar dan air laut untuk mendapatkan air payau bersalinitas 3\%, dapat digunakan dengan rumus (John,2011) sebagai berikut :

\section{$\mathrm{V} 1 \mathrm{xS1}=\mathrm{V} 2 \mathrm{xS} 2$}

Ket : 
V1: Volume air tawar

$\mathrm{S} 1$ : Salinitas yang diinginkan

V2: Volume air laut

S2 : Salinitas air laut

Selanjutnya setelah selesai pembuatan air untuk sampel lalu ambil jentik nyamuk tersebut, lalu masukan kedalam suatu wadah botol sampel. Pengambilan jentik nyamuk ini dilakukan dengan menggunakan pipet tetes. Kemudian masukan ekstrak batang nipah dan buah tersebut kedalam botol sampel denggan konsentrasi yang berbeda yaitu $3 \%, 6 \%$ dan $9 \%$.

Pada ekstrak batang dan buah nipah itu didiamkan selama beberapa menit hingga jentik nyamuk itu mati semua dan apakah daya bunuh pada ekstrak batang dan buah tersebut ada zat yang bisa membunuh larva nyamuk tersebut.

\section{Pembuatan Konsentrasi Ekstrak Nypa fruticans}

Pembuatan konsentrasi ekstrak $3 \%$, $6 \%$, dan $9 \%$ dilakukan dengan cara pemerasan. Ekstrak $N$. fruticans yang diencerkan dengan menggunakan aquades. Pertama konsentrasi air payau $97 \%$ lalu diambil $3 \mathrm{ml}$ air ekstraknya dan dicampur dengan air tawar sebanyak $97 \mathrm{ml}$ sehingga konsentrasi ekstrak larutan menjadi $100 \%$.

Konsentrasi air larutan sampel kedua dengan cara yang sama konsentrasi air payau $94 \%$ dan diambil $6 \mathrm{ml}$ ekstrak nipahnya dan dicampur dengan air tersebut $94 \mathrm{ml}$ sehingga dapat konsentrasi ekstrak larutan $100 \%$, lalu sampel ketiga konsentrasi air tawar nya sebanyak $91 \%$ dan diambil $9 \mathrm{ml}$ ekstrak nipahnya dan dicampur dengan air tersebut $91 \mathrm{ml}$ sehingga didapat konsentrasi ekstrak larut menjadi $100 \%$.

\section{Uji Efektivitas}

Uji efektivitas ekstrak $N$. fruticans terhadap jentik nyamuk yaitu dilakukan dengan metode eksperimen. Efektivitas pada ekstrak nipah (batang dan buah) berdasarkan prosedur dari World Health Organization Pesticides Evaluation Scheme (WHOPES) dapat ditentukan yaitu terdiri dari tiga konsentrasi, yaitu; $3 \%, 6 \%$ dan $9 \%$ serta aquades sebagai kontrol negatif. Masing masing perlakuan berisi 20 ekor larva nyamuk $A$. aegypti dengan pengulangan sebanyak 3 kali. Setiap perlakuan dilakukan pengamatan terhadap jumlah mortalitas larva tiap-tiap kelompok perlakuan pada masing-masing konsentrasi dalam 24 jam dengan berbagai interval waktu $(15,30,45,60,120,480$ menit) dengan cara menghitung $A$. aegypti yang mati ditiap patokan waktu dan dilakukan pengulangan selama dua hari.

Efektivitas ekstrak $N$. fruticans sebagai larvasida $A$. aegypti diukur dengan menghitung $\mathrm{LC}_{50}$, dan $\mathrm{LT}_{50}$ dengan menggunakan spss analisis probit. Uji dilanjutkan dengan Anova untuk mengetahui perbedaan signifikansi antar sampel penelitian

\section{Analisis Data}

Data yang diperoleh disajikan
kedalam bentuk tabel dan grafik. Selanjutnya data dianalisis secara deskriptif untuk melihat adanya perbedaan antar perlakuan, maka dilakukan dengan uji statistik One Way Anova. Data yang menunjukkan adanya perbedaan antar perlakuan dilakukan uji lanjut dengan uji Tukey.

\section{Hasil dan Pembahasan}

Keadaan kualitas suatu perairan adalah hal yang sangat penting bagi suatu kehidupan organisme. Secara umum pertumbuhan organisme dipengaruhi oleh parameter kualitas perairan yang meliputi suhu, derajat keaasaman $(\mathrm{pH})$ dan salinitas. 
Hasil pengukuran kualitas air di Perairan Desa Sungai Kayu Ara dapat dilihat pada

Tabel 3. Hasil Pengukuran Parameter Kualitas Air
Tabel 3.

KEPMEN LH (Keputusan Menteri Lingkungan Hidup) No 51 Tahun 2004.

Prosentase Kumulatif Kematian Larva

\begin{tabular}{cccc}
\hline No. & Parameter & Satuan & Hasil Pengukuran \\
\hline 1 & Suhu & ${ }^{\circ} \mathrm{C}$ & 30 \\
\hline 2 & Salinitas Air Laut & $\mathrm{Ppt}$ & 25 \\
\hline 3 & Salinitas Air Tawar & $\mathrm{Ppt}$ & 1 \\
\hline 4 & $\mathrm{pH}$ & $\mathrm{Ppt}$ & 5 \\
\hline
\end{tabular}

Berdasarkan Tabel 3 dapat dilihat bahwa suhu perairan $30^{\circ} \mathrm{C}$, derajat keasaman $(\mathrm{pH})$ diperoleh 5 dan salinitas perairan diperoleh 25 ppt. Hasil pengukuran tersebut dapat disimpulkan perairan tersebut mendukung pertumbuhan organisme karena telah memenuhi baku mutu lingkungan hidup sesuai dengan

\section{Aedes aegypti}

Hasil analisis di laboratorium, menunjukan populasi larva pada setiap perlakuan mengalami kematian seiring dengan bertambahnya konsentrasi ekstrak yang diberikan. Untuk lebih terperinci dapat dilihat pada Tabel 4 berikut :

Tabel 4. Rata-rata Prosentase Kumulatif Kematian Larva Aedes aegypti pada Pengamatan setiap interval waktu selama 8 Jam Setelah Pemaparan dengan Bahan Uji Ekstrak Batang Nypa fruticans (P), ABATE (K+), dan Aquades (K-) ( $\mathrm{n}=20$ ekor)

\begin{tabular}{lccccccc}
\hline & \multicolumn{7}{c}{ Mortalitas (\%) } \\
\cline { 2 - 7 } & Konsentrasi & $15 \min$ & $30 \min$ & $45 \min$ & $60 \min$ & 120 min & 480 min \\
\hline P1 (3\%) & 0 & 5 & 10 & 15 & 65 & 100 \\
P2 (6\%) & 5 & 10 & 25 & 30 & 80 & 100 \\
P3 (9\%) & 15 & 30 & 40 & 70 & 95 & 100 \\
K (+) ABATE & 15 & 100 & 100 & 100 & 100 & 100 \\
K (-) Aquades & 0 & 0 & 0 & 5 & 5 & 5 \\
\hline
\end{tabular}

Tabel 5. Rata-rata Prosentase Kumulatif Kematian Larva Aedes aegypti pada Pengamatan setiap interval waktu selama 8 Jam Setelah Pemaparan dengan Bahan Uji Ekstrak Buah Nypa fruticans (P), ABATE (K+), dan Aquades (K-) (n=20 ekor)

\begin{tabular}{lcccccc}
\hline & \multicolumn{5}{c}{ Mortalitas $(\%)$} \\
\cline { 2 - 7 } \multicolumn{1}{c}{ Konsentrasi } & $15 \mathrm{~min}$ & $30 \mathrm{~min}$ & $45 \mathrm{~min}$ & $60 \mathrm{~min}$ & $120 \mathrm{~min}$ & $480 \mathrm{~min}$ \\
\hline P1 (3\%) & 0 & 15 & 30 & 65 & 80 & 100 \\
P2 (6\%) & 25 & 30 & 50 & 70 & 95 & 100 \\
P3 (9\%) & 15 & 40 & 70 & 80 & 100 & 100 \\
K (+) ABATE & 55 & 100 & 100 & 100 & 100 & 100 \\
K (-) Aquades & 0 & 0 & 0 & 0 & 5 & 5 \\
\hline
\end{tabular}

Hasil penelitian ini dapat mengetahui presentase kematian larva A.aegyptii terhadap pemberian ekstrak batang $\mathrm{N}$. fruticans pada berbagai konsentrasi. Pada Tabel 4 dan 5. Memperlihatkan bahwa tidak didapatkan kematian larva pada 
kelompok kontrol negatif selama 2 jam pengamatan, namun pada 4-8 jam paparan didapatkan kematian larva $A$. aegypti sebanyak $5 \%$ sedangkan pada kelompok kontrol positif didapatkan kematian larva uji sebesar $100 \%$ setelah 30 menit paparan. Pada kelompok perlakuan, terlihat adanya kematian larva $A$. aegypti sebesar $100 \%$ sudah terlihat sejak 45 menit paparan. Peningkatan jumlah kematian larva $A$. aegypti terjadi pada 45, 60, 120 dan 480 menit paparan. Terlihat bahwa semakin tinggi konsentrasi ekstrak batang dan buah $N$. fruticans maka semakin tinggi prosentase kematian larva A. aegypti.

Pada hasil penelitian ini menunjukkan bahwa untuk mematikan larva nyamuk A. aegypti, menggunakan berbagai konsentrasi dalam waktu 420 menit. Hal ini disebabkan karena metode ekstraksi yang digunakan untuk mendapatkan ekstrak batang dan buah nipah masih sangat sederhana menggunakan alkohol 70\%. Uji efektivitas ekstrak batang dan buah nipah yang efektif dalam membunuh larva nyamuk $A$. aegypti terjadi pada konsentrasi yang tinggi yaitu 9 $\%$. Ekstrak ini dijadikan biolarvasida karena mengandung senyawa-senyawa kimia berupa zat asetogenin seperti annonin atau annonasin (Wahyuni \& Loren, 2015).

Berdasarkan analisis probit, diketahui nilai $\mathrm{LC}_{50}$ pada batang $3,398 \%$ dan $\mathrm{LT}_{50}$ pada batang 4,192 jam, sedangkan pada buah nilai $\mathrm{LC}_{50}$ adalah $3,540 \%$ dan $\mathrm{LT}_{50}$ 3,033 jam. Nilai tersebut menunjukkan bahwa ekstrak batang dan daun nipah berpengaruh sebagai larvasida terhadap nyamuk $A$. aegypti. Kemampuan ekstrak batang dan buah nipah untuk membunuh 50\% larva didapatkan dalam konsentrasi $3,398 \%$ dan $3,540 \%$, sedangkan waktu yang dibutuhkan ekstrak batang dan buah nipah untuk membunuh 50\% larva adalah 4,192 jam dan 3,033 jam.
Hasil uji biolarvasida ekstrak nipah ini menunjukkan bahwa ekstrak nipah pada batang dan buah mengandung senyawa quinic acid dan terbukti memiliki potensi sebagai biolarvasida. Ini terlihat hasil Analisis probit berdasarkan tabel 6 dan 7 setelah dihitung memiliki nilai $\mathrm{LC}_{50} 3,398$ $\%$ dan 3,540 \% dan termasuk ekstrak yang cukup toksik. Hubungan antara $\mathrm{LC}_{50}$ dengan klasifikasi toksisitas relatif suatu zat kimia dinyatakan dalam Tabel 1 .

Mekanisme kematian larva disebabkan zat aktif fraksi etil asetat yang masuk ke dalam tubuh larva akan mengganggu alat pencernaan larva. Zat aktif ini juga akan menghambat reseptor perasa pada daerah mulut larva yang menyebabkan larva gagal mendapatkan stimulus rasa sehingga tidak mampu mengenali makanannya yang akhirnya berujung kelaparan hingga kematian (Edwards, 2004).

Berdasarkan tingkat toksisitas diketahui nilai $\mathrm{LC}_{50}$ pada batang adalah $3,398 \%$ yang berarti berada di tingkat cukup toksik dikarena berapa diantara range 501-5000\%, sedangkan nilai $\mathrm{LC}_{50}$ pada buah adalah 3,540\% juga berada diantara 501-5000\% dengan tingkatan yang cukup toksik yang dapat dilihat pada Tabel 1.

\section{Kesimpulan dan Saran}

\section{Kesimpulan}

Berdasarkan hasil penelitian yang telah dilakukan dapat disimpulkan bahwa ekstrak batang dan buah nipah mampu membunuh larva nyamuk $A$. aegypti dan dapat dijadikan larvasida. Ekstrak yang lebih efektif dalam membunuh larva nyamuk adalah ekstrak buah nipah dibandingkan dengan ekstrak batang nipah terlihat pada jumlah persentase kematian larva. Waktu kontak yang efektif dalam 
membunuh larva adalah 480 menit dengan konsentrasi $3 \%, 6 \%$ dan $9 \%$ dapat membunuh $100 \%$ larva.

\begin{abstract}
Saran
Pada penelitian ini perlu dilakukan penelitian lebih lanjut dalam hal proses ekstraksi yang lebih efektif, jenis pelarut, durasi maserasi serta diharapkan selanjutnya dapat menguji daya hambat terhadap bakteri patogen dan lain-lain.
\end{abstract}

\section{DAFTAR PUSTAKA}

1. Edwards, D. 2004. Environmental Effects of Mosquito Control, US Fish and WildlifeService,https://www.fws.gov/cno/refuges/DonEdwards/CCPPDFs/AppendixK4_EffectsofMosquitoControl.pdf. Diakses 17 Januari 2017, pukul 12.04.

2. Fitri, N., F.M., Nurlaili, A., Desto, dan D. O. L., Maria. 2016. Identifikasi Larva Nyamuk Pada Tempat Penampungan Air di Padukuhan Dero Condong Catur Kabupaten Sleman. Jurnal Kesehatan Masyarakat Andalas. 10 (2) : 172-178 hlm.

3. Kementerian Kesehatan Republik Indonesia. 2015. Profil Pengendalian Penyakit dan Penyehatan Lingkungan. Jakarta.

4. Saputra, S., 2016. Sebaran Mangrove Sebelum Tsunami Dan Sesudah Tsunami Di Kecamatan Kuta Raja Kota Banda Aceh. Jesbio journal, V(1), 23-29.

5. Sefrinus, M.D.K., F., Gergonius dan R.N., Dewi. 2018. Aktvitas Biolarvasida Ekstrak Daun Sirsak dan Serai Wangi Terhadap Larva Nyamuk Aedes aegypti. Jurnal Saintek Lahan Kering. Volume 1(1) 13-16 hlm.

6. Wahyuni, D. dan I., Loren. 2015. Perbedaan Toksisitas Ekstrak Daun Sirih (Piper betle L.) dengan Ekstrak Biji Srikaya (Annona squamosa L.) terhadap Larva Nyamuk Aedes aegypti $\mathrm{L}$. 